\title{
REGULATION OF REGIONAL COMPENSATION CLAIMS AGAINST THE TREASURE AND OTHER OFFICERS IN ARTICLE 64 LAW NUMBER 1 OF 2004 IN THE IUS CONSTITUENDUM CONTEXT
}

\author{
Pakpahan Alman P.*, Doctoral Candidate \\ Sudarsono, Professor \\ Noerdajasakti Setiawan, Permadi Iwan, Lecturers \\ Faculty of Law, University of Brawijaya, Malang, Indonesia \\ ${ }^{*}$ E-mail: almanhukum@gmail.com
}

\begin{abstract}
Article 64 paragraph (1) and paragraph (2) of Law Number 1 of 2004 concerning the State Treasury states firmly that the treasurer and other officials who have been appointed to compensate the state/regional losses in settlements with the dimensions of State Administrative Law may still be subject to administrative sanctions and/or criminal sanctions. And suppose the treasurer and other officials are processed under criminal law. In that case, the criminal decision does not relieve the claim for compensation that has been determined through a settlement with the dimensions of State Administrative Law. The regulation of such norms certainly raises legal issues, which have implications for the Treasurer and Other Officials whose demands for regional compensation have been determined, namely creating double sanctions, both sanctions for compensation claims (internal settlement), administrative sanctions (dismissed with respect) and criminal sanctions (jail, fines, and compensation). To overcome these legal problems, an alternative model for regulating regional compensation claims is needed in Article 64 paragraph (1) and paragraph (2) of Law Number 1 of 2004 against the Treasurer and Other Officials with justice and legal certainty in the future (ius constituendum).
\end{abstract}

\section{KEY WORDS}

Ius Constitunedum, treasurer, other officials.

One of the elements in the criminal act of corruption is the loss of state finances. Against state financial losses, the Corruption Law, both the old Law Number 3 of 1971 and the new Law Number 31 of 1999 in conjunction with Law Number 20 of 2001, stipulates a policy that state financial losses must be returned or replaced by the perpetrators of corruption. Judging from the aspect of how to solve it, various ways can be taken, starting from (1) Criminal Prosecution/Special Criminal (Corruption), (2) Civil Claims, (3) Treasury Claims, and (4) Claim for Compensation.

According to Law Number 31 of 1999, in conjunction with Law Number 20 of 2001, the return of state financial losses can be done through two legal instruments, namely criminal instruments, and civil instruments. Criminal instruments are more commonly used because the legal process is simpler and easier. The investigator carries out the criminal instrument by confiscating the property belonging to the perpetrator and subsequently by the public prosecutor being demanded to be confiscated by the judge. Civil instruments are carried out by the State Attorney or institutions that have been harmed by the perpetrators of corruption (suspects, defendants, convicts, or their heirs if the convict dies).

In addition to the criminal and civil methods mentioned above, on the other hand, some administrative methods or approaches have long been practiced in the internal bureaucracy which are also strengthened by various provisions of laws and regulations, namely Law Number 15 of 2006 concerning the Supreme Audit Agency of the Republic of Indonesia. Law Number 1 of 2004 concerning State Treasury, and Law Number 17 of 2003 concerning State Finance Administrative instruments, institutionally carried out by the treasury demands assembly and compensation claims formed by the relevant department units or regional heads at all levels. 
The administrative approach practiced internally by the bureaucracy through treasury demands and demands for compensation can be classified as an internal control model for state/regional losses, both in the form of goods and money. In addition, this method can also be said as an effort to recover state/regional financial losses before further action is taken through the legal process. However, in practice, it is not uncommon for perpetrators (treasurers and other officials) who are subject to treasury demands and compensation claims before completing this process. In fact, they are faced with a criminal legal process. When the criminal legal process has been decided, the treasury demands and claims for compensation that have been determined by the team internally are still billed and must be paid by the perpetrators.

This means that the criminal decision does not free the perpetrator from the compensation claim. This is under the provisions in Article 64 of Law Number 1 of 2004 concerning State Treasury, which states: Paragraph (1) treasurer, non-treasurer civil servants, and other officials who have determined to compensate the state/regional losses may be subject to administrative sanctions and/or criminal sanctions paragraph (2) of the criminal decision does not exempt from the compensation claim. Then in Article 14 paragraph (1) of Law Number 15 of 2004 concerning Audit of State Financial Management and Responsibility, if a criminal element is found during the examination, the BPK immediately reports the matter to the competent agency under the provisions of the legislation.

Based on Law Number 1 of 2004 concerning the State Treasury, it regulates treasury claims and claims for compensation, as regulated in Chapter XI of Settlement of State/Regional Losses starting from Article 59, Article 60, Article 61, Article 62, Article 63, Article 64, Article 65, Article 66 and Article 67. Of the nine articles, several articles and paragraphs form the legal basis for the authority to carry out treasury claims and claims for compensation. Of the nine articles, one of the articles that raise legal problems for the author is Article 64, paragraph (1) and paragraph (2) of Law Number 1 of 2004 concerning the State Treasury. In the author's view, when this article is applied, the treasurer and other officials will create double sanctions, both sanctions for compensation claims (internal settlement), administrative sanctions, and criminal sanctions.

The norm of Article 64 paragraph (1) and paragraph (2) of Law Number 1 of 2004 concerning the State Treasury contains a lack of clarity/inconsistency of norms which results in the ineffectiveness of recovering state/regional financial losses using compensation through treasury claims. Because the perpetrators do not want to pay the compensation because they have been sentenced to imprisonment, fines and additional criminal compensation for money. Administrative sanctions are also imposed in the form of dishonorable dismissal. Even though he has undergone a court decision, the person concerned is still being billed by the BPK through the Regional Government (the Inspectorate and the State/Regional Financial Loss Settlement Team).

The existence of billing and the condition of being unable to pay by the person concerned has implications for his legal status. Depending on one's legal status, it is certainly contrary to the principles of human rights and the principle of the rule of law as regulated in the 1945 Constitution of the Republic of Indonesia. Article 1 paragraph (3) of the 1945 Constitution of the Republic of Indonesia states that the State of Indonesia is a state of law. As a state of law, everyone has the right to recognition, guarantee, protection, and fair legal certainty, and equal treatment before the law (Article $28 \mathrm{D}$ paragraph (1) of the 1945 Constitution of the Republic of Indonesia).

Based on the explanation above, the ambiguity/inconsistency of the norms of Article 64 paragraph (1) and paragraph (2) of Law Number 1 of 2004 concerning the State Treasury became the basis of the author's interest in studying the model for setting claims for regional compensation against the Treasurer and Other Officials justice and legal certainty in the future (ius constituendum).

Based on the explanation of the background above, the problem can be formulated, namely, How is the model for the future arrangement (ius constituendum) for Claims for 
Regional Compensation for Treasurers and Other Officials in Article 64 of Law Number 1 of 2004 that is fair and has legal certainty?

\section{METHODS OF RESEARCH}

This research is legal research using a statutory approach. The legal materials used are primary, secondary, and tertiary legal materials analyzed using analytical descriptive.

\section{RESULTS AND DISCUSSION}

Restorative Justice Approach by Optimizing the Settlement of State/Regional Financial Losses by Administrative Law. Restorative justice is a concept to restore state financial losses and avoid more significant losses. As the meaning and nature of restorative justice is known in the idea of criminal law, criminal law policy through this restorative justice approach can be used to avoid the impact of more significant losses and eliminate the effects of the emerging crisis. Regarding restorative justice, or in Indonesian terms called restorative justice, it is a form of a new approach model in settlement of criminal cases. This restorative justice approach model has been used in several countries, focusing on its approach to perpetrators, victims, and the community in resolving legal cases between them. Although this approach model is still widely debated at the theoretical level by experts, it continues to grow and exist. It influences policy and legal practice in many countries.

The principles of restorative justice can be interpreted as a model for resolving cases outside the court or often referred to as out-of-court settlement, which pays more attention to justice, the goals and desires of the parties with the concept of victim awareness work. In the normative framework as well as from the theoretical framework, the principle of settlement of criminal cases outside the court or out-of-court settlement is widely questioned, but in reality, there are also several practices of settlement of criminal cases outside the criminal justice system.

Can it be used with this concept from the explanation above regarding restorative justice related to the settlement of state/regional financial losses? In the author's view, restorative justice is an effective and efficient means of optimizing the return of state/regional financial losses. Because if it is taken into account in managerial accounting whether restorative justice is effective or not, we will show it in the future without compromising the sense of justice for the community. To eradicate corruption, the point is to restore financial losses or the state's economy, so it is necessary to consider the application of the concept of restorative justice in settlement of state/regional financial losses.

A restorative justice approach in resolving state/regional financial losses by treasurers and other officials by optimizing administrative, legal settlements through treasury claims or compensation without being accompanied by administrative sanctions (disrespectful dismissal) and criminal sanctions (in the form of imprisonment and fines) as well as additional criminal compensation is essential to apply. According to the author, the reason is to avoid failure in the context of recovering state/regional financial losses by treasurers and other officials. Besides that, convicts rarely obey to prevent the accumulation of cases and the non-maximum return of state/regional financial losses through criminal means (fines and compensation).

In many cases, especially those that occurred in the Palangka Raya City Government, for example, the case of state/regional financial losses carried out by the treasurer, when a treasury claim has been made in the form of compensation, it should not be prosecuted and go to court. It is said that because of the judge's decisions in these and other similar cases, many convicts are reluctant to carry out their obligations. This is due to the double sanctions received by the treasurer as the perpetrator of state/regional financial losses and causing it not to fulfill a sense of justice. The author considers that law enforcement officers, the police and prosecutors, should not take the case to court because it can be resolved through settlement patterns agreed upon by both parties (treasurer and the State Financial Loss Settlement Team). This becomes interesting to discuss, considering that the nature of 
criminal law is ultimum remidium which means the last resort if there is no other effort to resolve the case. However, in its development, criminal law is used as the first effort to solve a problem between the perpetrator and the state.

Forms of Restorative Justice in Corruption Crimes. The main target of Law Number 20 of 2001 concerning the Eradication of Corruption Crimes is the return of state financial losses. Law enforcement officials are expected to be able to identify criminal acts of corruption cases that are considered detrimental to state finances so that they can be resolved through out-of-court settlements by calculating the comparison of the value of operational funds for handling cases with the value of state financial losses.

An out-of-court settlement is a concept of restorative justice. The application of restorative justice needs to be accommodated to evaluate the weaknesses of the retributive justice approach as it has existed and is in effect (Suhariyanto, 2016). Marwan argues that Restorative justice can be used in criminal acts of corruption, unlike restorative justice in general crimes, which must involve the involvement of victims, perpetrators, and the community related to corruption issues that focus on restoring state losses. Didik Endro Purwoleksono states that (Purwoleksono, 2016) If the suspect or defendant returns all the proceeds of a criminal act of corruption, it can essentially be used as a factor that eliminates the nature of being against criminal law, namely the crime of corruption so that the suspect or defendant does not need to be convicted. There are 3 (three) elements or conditions that cause the loss of the unlawful nature of a criminal act of corruption, namely (Purwoleksono, 2016):

- The suspect or defendant does not benefit;

- The state is not harmed;

- The community is served.

Based on this explanation, it can be analyzed that if the perpetrator of a criminal act of corruption has returned all the proceeds of the crime of corruption along with all the profits derived from the proceeds of the criminal act of corruption by the perpetrator of a criminal act of corruption, then basically the perpetrator has not benefited, the state has not suffered financial losses. The community can be served through the return of all proceeds of corruption and all the profits. The purpose of the community being served is that the state can build facilities that are useful to the wider community by returning all the proceeds of corruption and all the profits.

Suppose the perpetrator of a criminal act of corruption only returns a portion of the proceeds from a criminal act of corruption. In that case, the perpetrator still benefits from the criminal act of corruption he has committed, and the state is still at a loss, and the community is not served. So that the return of the proceeds of a criminal act of corruption which is only partially cannot eliminate its unlawful nature, the proceeds of a criminal act of corruption must be returned by the perpetrator of a criminal act of corruption in its entirety to eliminate the unlawful nature of the perpetrator. The return of all the proceeds of the criminal act of corruption along with the profits obtained by the suspect or defendant has consequences (Purwoleksono, 2016):

- Does not cause victims and/or losses, in which case there is no state loss;

- Other means are more effective and with fewer losses in tackling acts considered disgraceful. In this case, the state does not need to spend more money to process, convict, and provide food and drink to convicts of corruption.

So, with the implementation of restorative justice in corruption in the form of returning all proceeds of corruption by perpetrators of corruption, it can be said that it is more profitable for the state. With the implementation of restorative justice, the state is not burdened with finances to process and feed perpetrators of corruption detained or convicted. If the retributive justice model is applied, it is feared that the perpetrators of criminal acts of corruption will choose to undergo a substitute punishment in the form of imprisonment rather than paying losses to the perpetrator's country. This, of course, is increasingly detrimental to the country.

Didik Endro Purwoleksono argues that the application of restorative justice in the form of returning all proceeds of corruption can be carried out at the time (Purwoleksono, 2016): 
- Before the investigation;

- At the time of the investigation;

- At the time of the investigation; and

- During the examination before the court.

With the return of all the proceeds of a criminal act of corruption obtained by the perpetrator, it can eliminate the element of mens rea or malicious intent in the perpetrator, so that if the perpetrator returns all the results of a criminal act of corruption at the investigation level, the investigator can state that the case cannot be escalated to the investigation stage. In contrast, the investigator may issue an Order for Termination of Investigation at the level of investigation. One of the reasons for issuing the Order to Terminate Investigation under Article 109 of the Criminal Procedure Code is that it is not a criminal act. The return of all proceeds from the criminal act of corruption by the perpetrator has the consequence of losing the unlawful nature of the perpetrator of the criminal act of corruption. Thus, it can be said that the case is not a case of a criminal act of corruption.

Furthermore, at the trial stage, Didik Endro Purwoleksono argues that (Purwoleksono, 2016) The return of all proceeds of criminal acts of corruption along with all profits obtained by the defendant during the examination in court, then this can be a court decision is to release the defendant from all lawsuits or onslag van recht vervolging.

What was indicted by the public prosecutor was indeed proven, but due to the unlawful nature of the If the perpetrator is missing, the case is not a criminal act of corruption. The court's decision is in the form of being free from all lawsuits or onslag van recht vervolging, not vrijspraak (Purwoleksono, 2016). Thus, the application of restorative justice in criminal acts of corruption in the form of returning all the proceeds of criminal acts of corruption can be carried out at the stage before the investigation, during investigation and investigation, even during examination in court. This is in accordance with the provisions of Article 191 paragraph (2) of the Criminal Procedure Code, with the return of all proceeds of a criminal act of corruption by the perpetrator causing the consequence of the loss of the unlawful nature of the perpetrator of the criminal act of corruption.

Application of Restorative Justice in Criminal Acts of Corruption in Indonesian Law. The national working meeting in 2011 held by the Supreme Court resulted in an important decision which can then become jurisprudence in the decision of the Supreme Court, which is based on Decision Number $1600 \mathrm{~K} / \mathrm{Pid} / 2009$ concerning Restorative Justice Considerations. In principle, this jurisprudence can be said to be the seed of the birth of restorative justice, because according to the Supreme Court, one of the goals of criminal law is to restore the balance that occurs because of a crime. One of the goals of "restoring the balance" in corruption is to restore state financial losses for the benefit of the general public and anticipate crises in various fields of state development (Rusianto, 2015).

Restorative justice is recognized by the international community, namely in 2000 held by the United Nations, Basic Principles on the use of restorative justice programs in criminal matters concerning several fundamental principles of using a restorative justice approach. In Chapter 9 of the United Nations Convention on Restorative Justice, efforts have been made to apply it in several countries in the world, such as the United Kingdom, Austria, Finland, Germany, the United States, Canada, Australia, South Africa, Gambia, Jamaica, and Colombia. According to the former Deputy Chief Criminal of the Supreme Court of the Republic of Indonesia, Artidjo Alkostar that many minor criminal cases can actually be processed on the principle of a fast, low cost, and simple trial. For example, people steal bananas because they are hungry, and the banana owner can forgive. The ethical consequences do not need to be decided in court but are resolved through penal mediation.

In general, the basic principles from other examples of restorative justice through mediation determine several prerequisites for restorative justice, for example, domestic violence or sexual harassment, namely:

- Victims of crime must consent;

- violence must stop;

- Criminals must take responsibility; 
- Only the perpetrators of the crime should be blamed, not the victims;

- The mediation process can only take place with the victim's consent.

Restorative justice is currently not specifically regulated in the legislation on corruption in Indonesia, but based on the case of Decision Number 1600 of 2009, is due to the existence of Article 10 paragraph (1) of Law Number 48 of 2009 concerning Judicial Powers that judges cannot refuse to examine, try, and decide on a case because the law does not exist or is unclear. The reason is that there is no law or it is unclear in principle in Article 5 paragraph (1) of Law Number 48 of 2009 concerning Judicial Powers that judges have a way to find them or, in other words, make legal discoveries, so judges are obliged to continue to examine and try them. Therefore, Restorative justice in principle can reduce the socioeconomic burden of the state and the energy of law enforcement in providing justice for the community. For this reason, the existence of a restorative justice institution needs to be included in the criminal justice system.

Corruption has been enacted by Circular in several law enforcement agencies including, but has not yet been established through legislation:

- Police Chief Letter No. Pol. B/3022/XII/2009/sdeops regarding the concept of Alternative Dispute Resolution (ADR), in the first point it is written that the handling of criminal cases that have small material losses, the settlement can be directed through the concept of ADR which has similarities with Restorative Justice which prioritizes deliberation between parties involved;

- Circular Letter of the Deputy Attorney General for Special Crimes Number: B113/F/Fd.1/05/2010 dated 18 May 2010, one of the points in its content is to instruct all High Prosecutor's Offices which contains an appeal that in cases of alleged corruption crimes, the public should awareness of having returned the loss to the state needs to be considered not to be followed up on the application of the principle of restorative justice.

Corruption has also been implemented in terms of the implementation of abuse of authority in Government Administration from Article 17 of Law Number 30 of 2014 concerning Government Administration that abuse of authority is emphasized in Article 34 of Government Regulation of the Republic of Indonesia Number 48 of 2016 concerning Procedures for Imposing Sanctions Administrative To Government Officials to Government Officials can be returned to the state/regional treasury. This means that if from a result of supervision by the Government Internal Supervisory Apparatus (APIP), even though there is an administrative error that results in loss of state money, the state financial loss shall be refunded no later than 10 (ten) working days as of the decision and issuance of the results of the supervision.

Changes to the Norms of Article 64 paragraph (1) and paragraph (2) of the State Treasury Law. Based on the explanation of the restorative justice approach by optimizing the settlement in Administrative Law above, it is related to the existence of the contents of Article 64 paragraph (1) and paragraph (2) of Law Number 1 of 2004 concerning the State Treasury, according to the author it is necessary to make amendments or changes which emphasizes the principles of justice and legal certainty, both for treasurers and other officials, the community and the state as victims of corruption. The contents of the norms of Article 64 paragraph (1) and paragraph (2) of Law Number 1 of 2004 concerning the State Treasury may be amended or amended as follows:

- The treasurer, non-treasurer civil servant, and other officials appointed to compensate the state/regional losses may be subject to administrative and/or criminal sanctions.

According to the author, the amendment to paragraph (1) is that the treasurer and other officials who have been appointed to compensate the state/regional losses are sufficient to compensate for the losses and administrative sanctions. The administrative sanctions do not include severe administrative sanctions, provided that the person concerned complies and fulfills his obligations to pay compensation for state/regional financial losses. Unless the person concerned is unwilling or negligent or fails to pay to carry out his obligation to compensate the state/regional financial loss through an internal 
settlement, the settlement may be transferred through criminal means. That is, prioritizing the administrative law settlement to completion, only then can the criminal law instrument be carried out when the administrative law instrument fails to resolve the issue. This is the same as the ultimum remedium concept, as one of the principles contained in Indonesian criminal law, which says criminal law should be used as a last resort in law enforcement, and it is considered that there is still an alternative solution other than applying a criminal law rule.

- The criminal decision does not exempt from the compensation claim.

Changes to this paragraph need to be made, considering that in many cases, the author has encountered that treasurers and other officials who have been convicted of a crime are still being charged for compensation, they do not want to complete the obligations imposed on them because they have served corporal punishment, fines, and compensation. According to the author, the compensation claim will be removed to avoid double sanctions when a criminal verdict has been handed down. Because the criminal decision has been determined, the prison sentence for the treasurer and other officials will also be accompanied by a fine and additional punishment for replacement money.

\section{CONCLUSION}

Based on the discussion above, the authors can conclude that the model for the future arrangement (ius constituendum) for Regional Compensation Claims against Treasurers and Other Officials is fair and has legal certainty, namely through a restorative justice approach by optimizing the settlement of state/regional financial losses under Administrative Law. Furthermore, it is necessary to make changes to the norms of Article 64 paragraph (1) and paragraph (2) of the State Treasury Law, which includes:

- Amendment to paragraph (1), namely prioritizing administrative-legal settlement to completion, only then can criminal law instruments be carried out if administrative law instruments fail to resolve the issue. This is the same as the ultimum remedium concept, as one of the principles in Indonesian criminal law, which says criminal law should be used as a last resort in law enforcement. It is considered that there is still an alternative solution other than applying a criminal law rule;

- Changes in paragraph (2) need to be made, meaning that when a criminal decision has been handed down, the compensation claim will be deleted to avoid double sanctions. Because the criminal decision has been determined, the prison sentence for the treasurer and other officials will also be accompanied by a fine and additional punishment for replacement money.

\section{REFERENCES}

1. Muhlizi, A.F. (2014). Revolusi Mental Untuk Membentuk Budaya Hukum Anti Korupsi. Jurnal RechtsVinding Media Pembinaan Hukum Nasional, 3 (3).

2. Muqoddas, B. (2014). Kebijakan Penangulangan Korupsi di Indonesia. Solo: Program Doktor Sekolah Pascasarjana UMS.

3. Purwoleksono, D.E. (2016). Hukum Pidana Untaian Pemikiran. Surabaya: Airlangga University Press.

4. Ruman, Y.S. (2012). Keadilan Hukum dan Penerapannya dalam Pengadilan. Jurnal Humaniora, 3 (2).

5. Rusianto, A. (2015). Tindak Pidana dan Pertanggungjawaban Pidana: Tinjauan Kritis Melalui Konsistensi antara Asas, Teori, dan Penerapannya. Jakarta: Kencana.

6. Suhariyanto, B. (2016). Restorative Justice dalam Pemidanaan Korporasi Pelaku Korupsi Demi Optimalisasi Pengembalian Kerugian Negara. Jurnal Rechtsvinding, 5 (3).

7. Wijayanta, T. (2014). Asas Kepastian Hukum, Keadilan dan Kemanfaatan dalam Kaitannya dengan Putusan Kepailitan Pengadilan Niaga. Jurnal Dinamika Hukum, 14 (2). 